\title{
Predicting heave on the expansive soil
}

\author{
Willis Diana ${ }^{1, *}$, Anita Widianti $^{1}$, Edi Hartono ${ }^{1}$, and Agus Setyo Muntohar ${ }^{1}$ \\ ${ }^{1}$ Civil Engineering Department, Universitas Muhammadiyah Yogyakarta, Yogyakarta, Indonesia
}

\begin{abstract}
The heave of expansive soil information is a fundamental part of the preparation of a foundation design to accommodate the anticipated volume change and consequences associated with the foundation movement over the design life of the structure. The one-dimensional oedometer is the most widely accepted method to identify and evaluate the amount of swell that may occur. Although the oedometer is used extensively for evaluating the amount of heave, the procedures used are quite varied, and few of the methods have been validated experimentally. An objective of this research study is to briefly explain common practices and existing heave prediction by oedometer methods and then, to validate by experimental laboratory heave tests using soil sample from Ngawi. The two prediction methods provided results that represent low and upper bound predictions of the actual soil heave movement in the laboratory. The difference between the prediction with heave measurement is about $29,50 \%$ and $45,02 \%$, respectively.
\end{abstract}

\section{Introduction}

The expansive soil has a potential to increase and decrease in volume under increasing and decreasing water content and as well as suction. The swelling pressure will be imposed on infrastructures such as the foundation slab, highway pavements, tunnels, pipelines, and consequently, results in extensive damages. Expansive soils cause more damage to structure, particularly to light buildings and pavements. The reliable determination or estimate of the swelling pressure and the amount of anticipated heave that soil will undergo when subjected to variance in water content is the key information that determines the success of the remediation techniques and procedures [1] and is essential for the development of more effective and economical designs of structure on expansive soil [2]. Recently, several procedures have been proposed to estimate the swelling pressure, swell potential and soil movement prediction. The study not only used the 1-D analysis [3] [4] but also the 3-D [5] [6] [4]. The one-dimensional oedometer is the most widely accepted method to identify and evaluate the amount of swell that may occur, but the procedures used are quite varied. Furthermore, numerous numerical methods have been developed for the estimation of heave

\footnotetext{
* Corresponding author: willis.diana@umy.ac.id
} 
(swell in the vertical direction), but few of these methods have been validated experimentally, and there is a limited amount of experience regarding the reliability of the available prediction methods [7].

The purpose of this paper is to review recent research into the heave prediction focused on the oedometer method and validated the method experimentally, aiming to provide the most suitable method that can be used for predicting heave of the expansive soil from Ngawi, East Java. The study was conducted in the form of laboratory work, with data being gathered via investigating swelling properties using oedometer test, modeling soil heave (swelling) in the testing box, measuring the heave, and comparing heave measurement with the heave prediction analysis.

\section{Oedometer and heave prediction}

The oedometer test is a one-dimensional test in which a soil sample is confined laterally and subjected to vertical stress while being wetted. The use of the oedometer test is to measure the amount of swell that may occur. For expansive soils three basic types of oedometer tests are standardized, commonly performed to determine the swelling and swell pressure as follows: The swell-consolidation method (CS), The constant volume (CV), and the swell overburden method (SO) [9]. Procedures for the three kinds of test are described by the ASTM D4546 [10]. The swelling pressure obtained from the three oedometer methods was different. The SC test gave an upper bound value for swelling pressure, the swell overburden (SO) test provided the smallest value, and the constant volume (CV) test gave an intermediate value [7] [11] [12]. The large difference in swelling pressure among the oedometer method was mainly attributed to the effect of side friction, the test wetting, and loading conditions [12].

In the late 1950's, heave prediction methods were first developed in which it originated as an extension of methods used to estimate volume changes due to consolidation in saturated soils using results of one-dimensional oedometer (consolidation) tests [8] [13].

\subsection{Marr et al. method [3]}

Marr et al. [3] proposed a practical method to predict the vertical movement (heave) of the soil base on changes in water content. A simple method for predicting vertical strain $\left(\varepsilon_{\mathrm{v}}\right)$ as a function of changes in water content $(\Delta \mathrm{w})$ at a given total applied vertical stress $\left(\sigma_{\mathrm{v}}\right)$ was proposed.

The series of test were conducted to determine that the soil behaves under field stress conditions with seasonal changes in moisture content. The measured volume strains (or changes in void ratio) are plotted against the change in water content. Marr et al. [3] used fixed ring consolidation cells to measure the shrink-swell properties. In each test, the total applied vertical stress on the soil specimen was held constant, which represents a typical pressure range where expansive soil behavior would be a concern. Three shrink-swell (e.q. in-situ to wet, in-situ to dry, and dry to wet) tests were performed to obtain the relationship between vertical strain $\left(\varepsilon_{v}\right)$ and water content variation $(\Delta w)$ at a given total applied stress $\left(\sigma_{v}\right)$. For constant applied stress conditions, the response was found to be approximately linear in the region representing typical seasonal changes in soil moisture. As expected, the slope of swelling line $\left(C_{\varepsilon, w}=\varepsilon / \Delta w\right)$ decreases at higher applied stresses, indicating less expansion. The result was also plotted regarding void ratio $(e)$, water content $(w)$ and vertical stress $\left(\sigma_{v}\right)$. 
The water content was measured only at the start and end of each test series, that represent the initial and final soil conditions. The slope of lines $C_{e, w}$ for constant applied stress is related to the initial void ratio, $C_{e, w}=C_{\varepsilon, w} /\left(1+e_{o}\right)$. These test results define a constitutive model surface that can be used to predict volumetric changes due to variation in water content. The total surface displacement due to changes in water content became,

$$
\Delta H=H_{0} \times \frac{\Delta w \times C_{\varepsilon, w}}{100}
$$

where,

$\Delta H=$ the ground surface movement (heave),

$H_{0} \quad=$ the thickness of soil layer,

$\Delta w=$ changes in water content,

$C_{\varepsilon, w}=$ slope of swelling line,

\subsection{Nelson et al. method [14]}

The results of both the consolidation-swell (CS) test and the constant volume (CV) test are shown in fig. 1, as the paths GBA and GFE, respectively.

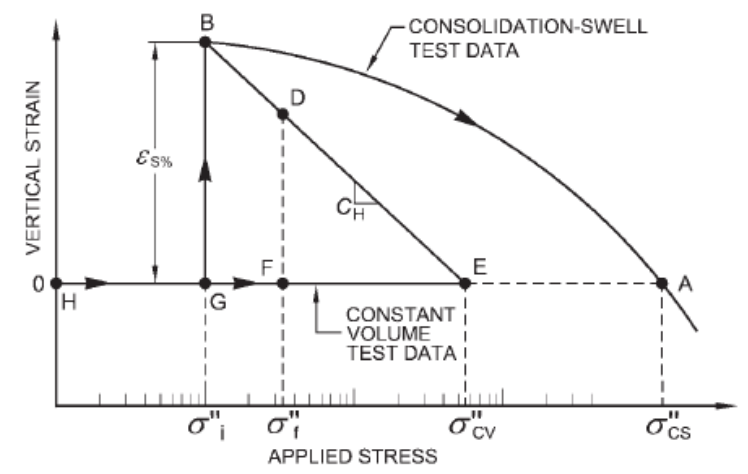

Fig. 1. Determination of Heave Index, $\mathrm{C}_{\mathrm{H}}$ (after [8]).

The heave index parameter $C_{H}$ is the slope of the line BDE in fig. 1, which is the ratio of the percent swell observed in the oedometer test to the vertical stress applied to the sample when it was inundated and is given by the equation as follows,

$$
C_{H}=\frac{\% S_{A}}{\log \left[\frac{\sigma_{c v}^{\prime}}{\left(\sigma_{i}^{\prime}\right)_{A}}\right]}
$$

and the equation for the heave prediction is,

$$
\Delta H=H C_{H} \log \left[\frac{\sigma_{c v}^{\prime}}{\sigma_{v o}^{\prime}}\right]
$$


where,

$\% S_{A}=$ percent swell corresponding to the particular value of $\sigma^{\prime \prime}{ }_{i}$ expressed as a percent,

$C_{H}=$ heave index,

$\sigma_{c v}^{\prime}=$ swelling pressure from constant swell test,

$\sigma_{v o}^{\prime}=$ vertical stress at the midpoint of the soil layer for the condition under which the heave being computed

\section{Material and method}

\subsection{Soil samples}

An expansive soil from Ngawi, East Java was used for this study. Disturbed sample was collected from a location at a depth of 1-2 m below the ground level. The soil was air dried, pulverized and then sieved through a no. 10 test sieve. The X-ray diffraction spectra gave the following mineralogical composition - montmorillonite: $64 \%$ and andalusite: $35.9 \%$. The physical properties of the soil are presented in Table 1.

Table 1. Geotechnical properties of the materials.

\begin{tabular}{|l|l|}
\hline Soil Properties & Value \\
\hline Specific gravity & 2.65 \\
\hline Liquid limit (LL); Plastic Limit (PL); Shrinkage Limit (SL) (\%) & $94.39 ; 34.58 ; \quad 11.63$ \\
\hline Percentage finer $<2 \mu \mathrm{m}(\%)$ & 96.32 \\
\hline USCS and AASTHO classification & $\mathrm{CH} \& \mathrm{~A}-6-7$ \\
\hline Maximum Dry Density $(\mathrm{kN} / \mathrm{m} 3)$ & 12.26 \\
\hline Optimum Moisture Content $(\%)$ & 35.55 \\
\hline Swelling Pressure $(\mathrm{CS}$ method) $(\mathrm{kPa})$ & 140 \\
\hline
\end{tabular}

\subsection{Heave test on testing box}

The heave test was performed in the testing box with dimensions of $125 \mathrm{~cm}$ in width, $125 \mathrm{~cm}$ in length, and $125 \mathrm{~cm}$ in depth. All internal sides of the testing box are covered with a plastic layer. The testing box has sand at the bottom with a depth of $50 \mathrm{~cm}$; then the expansive soil is spread above the sand layer at a dry unit weight of $12.26 \mathrm{kN} / \mathrm{m} 3$ and average initial soil moisture content of $11.22 \%$. The expansive soil is compacted, and the depth of the expansive soil layer is $50 \mathrm{~cm}$. The uniformity in the soil bed is checked by measuring the unit weight and moisture content at various depths of the soil by using the core cutter method. The expansive soil wetted gradually to induce soil expansion by adding the water from the top. Heave stakes are used to measure heave changes that occur in depth. Heave stakes are used as a displacement plate in field consolidation settlement measurements. In this test, the five heave stakes were used to measure heave changes respectively in any depth of $10 \mathrm{~cm}$. A digital calliper was used to measuring it. The heave and water content changes were measured, recorded and continuously monitored with time until there is no further significant heave. The final free field heave measured in heave test is shown in Table 2. 
Table 2. The free field heave measured in the heave test on laboratory

\begin{tabular}{|c|c|c|c|c|c|c|}
\hline Depth (cm) & 0 & 10 & 20 & 30 & 40 & 50 \\
\hline Heave (cm) & 10.89 & 8.44 & 6.35 & 4.55 & 1.74 & 0 \\
\hline
\end{tabular}

\subsection{Oedometer test}

The consolidation-swell (CS) test was used to identify the swelling properties of the soil samples. The series of CS tests was performed to obtain some parameters that is needed in the heave prediction analysis. For the swelling properties measurement, an oedometer frame and conventional oedometric cell were used. The specimens were compacted directly into the oedometric ring $(6,35 \mathrm{~mm}$ in diameter and $20 \mathrm{~mm}$ in height). The initial height of the specimens was approximately $17 \mathrm{~mm}$. The compacted soil sample was placed in a consolidation cell between air-dry porous stones. A vertical pressure exceeding the seating pressure is applied to the specimen before placement of free water into the oedometer. The specimen is given access to free water. This may result in the swell, swell then contraction, contraction, or contraction then swell. The swelling strain (swell percent) experienced by the specimen upon saturation is recorded as a function of time. The amount of swell or settlement is measured at the applied pressure after movement is negligible. The specimen is loaded after primary swell has occurred until its initial void ratio/height is obtained. The duration of the swell-consolidation test is approximately between 15 days-18 days.

\subsubsection{The data needed for heave predicting used Marr et. al. method [3]}

For testing under given vertical stresses, ten remolded dry specimens were made, with water content and dry unit weight $11.22 \%$ and $12.26 \mathrm{kN} / \mathrm{m} 3$, respectively. These water contents and dry unit weights were same with the soil condition on the heave test in a testing box. The specimens were placed in odometer cells and then submerged to allow free access to water at an atmospheric pressure. The maximum swell was measured with two specimens; The swelling was complete when the slope of vertical stain-log time curve decreases significantly, which occurred in approximately ten days under $3.3 \mathrm{kPa}$. The remaining soil specimens were then allowed to swell under the same stress for 60, 240, 1440, 4320, and 14400 minutes. Before swelling was complete, these tests were stopped to determine the change in water content corresponding to measured intermediate strain levels. The swell curve for ten specimens was almost similar but terminated at different times before the swelling is complete. These tests were duplicated for vertical stress $8.8 \mathrm{kPa}$ and $12.5 \mathrm{kPa}$. These vertical stresses were calculated from the overburden pressure from the soil surface to the middle depth of the clay bed. The measured vertical strains are plotted against the change in water content as shown in fig. 2a. The linear relationship between vertical strain and the change in water content was observed. At higher applied stress, the slope of swelling line decreases $(\mathrm{C} \varepsilon, \mathrm{w}=\varepsilon \mathrm{v} / \Delta \mathrm{w})$. Fig. $2 \mathrm{~b}$ was showing the relation between the slope of $\mathrm{C} \varepsilon, \mathrm{w}$, and applied stress. 
(a).

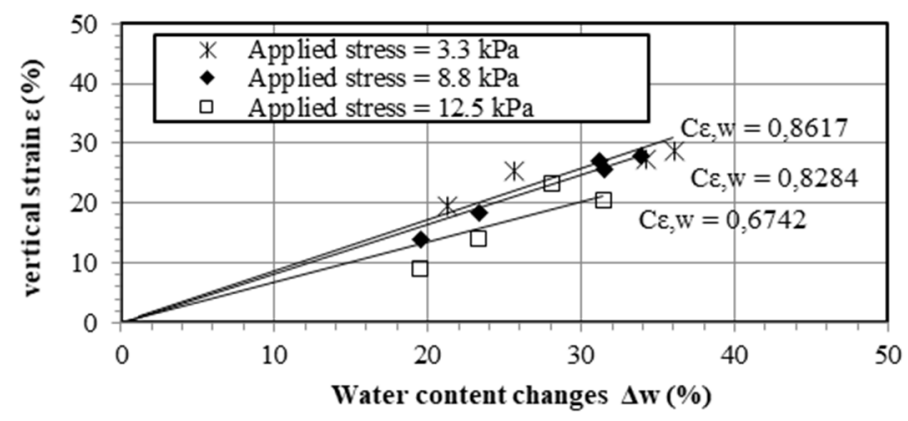

(b)

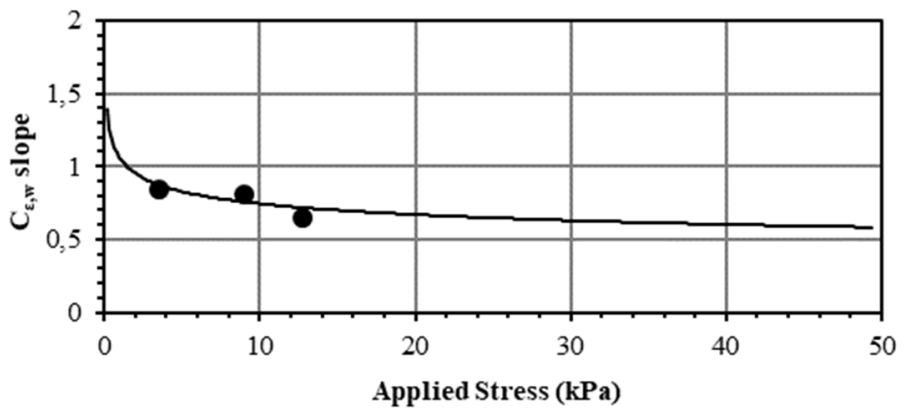

Fig. 2. (a) Response of strain to change in water content observed in swell test, (b) Relation between slope of $\mathrm{C}_{\varepsilon, \mathrm{w}}$ and applied stress.

\subsubsection{The data needed for heave predicting used Nelson et. al. (2006) method}

The swell pressure from the $\mathrm{sCV}$ and $\mathrm{CS}$ test are needed to determine the constitutive parameter $\mathrm{CH}$. But, in the routine geotechnical laboratory, only the CS test is conducted, hence only CS swelling pressure is measured. There are many procedures proposed to determine the $\mathrm{CH}$ parameter from just the single CS test [15] [16]. One of the proposed methods for determining $\mathrm{CH}$ parameters was the m method, as used in this study. The swell pressure from the CV test was approached by observation of the oedometer CS test result from a series of tests performed on identical samples [17]. The magnitude of applied stress used in this study was $1.2 \mathrm{kPa}, 6.90 \mathrm{kPa}, 10 \mathrm{kPa}, 20 \mathrm{kPa}$, and $40 \mathrm{kPa}$. The CS test result is as shown in fig. 3. From the test result it can be determined that the CV swell pressure $\left(\sigma^{\prime}{ }_{\mathrm{cv}}\right)$ was $88.85 \mathrm{kPa}$ and that the $\mathrm{CH}$ value calculated using equation (2) was 0.11 .

\section{Heave prediction analysis}

The heave that takes place with no other loads applied to the soil is known as free field heave [8]. Predicted free field heave was computed and compared using equation (1) (Marr et. al method) and equation (3) (Nelson et.al method), then validated by applying free field heave measured in laboratory heave tests. The depth of the expansive soil layer that was tested in the laboratory was $50 \mathrm{~cm}$. The soil profile was divided into five layers, each layer was $10 \mathrm{~cm}$ thick, and the heave of each layer was computed. The average stress $\sigma{ }^{\prime}$ over the thickness of the layer was equal to the overburden stress at the midpoint of the layer and the soil was assumed to have become fully wetted over the entire depth of the soil. In this laboratory heave test, the initial water content was $11.21 \%$, and the final water content was $47,42 \%$ (the final 
degree of saturation about $99 \%$ ), water content changes ( $\Delta w)$ for the entire depth was 36.21 $\%$. The dry density $\gamma \mathrm{d}$ of the soil was $12,26 \mathrm{kN} / \mathrm{m}^{3}$, and at the saturated condition, $\gamma_{\mathrm{sat}}$ was $19,30 \mathrm{kN} / \mathrm{m}^{3}$. The profile of incremental heave and total heave throughout the depth of heave is shown in Table 3 and Table 4, using equation (1) and using equation (3) respectively.

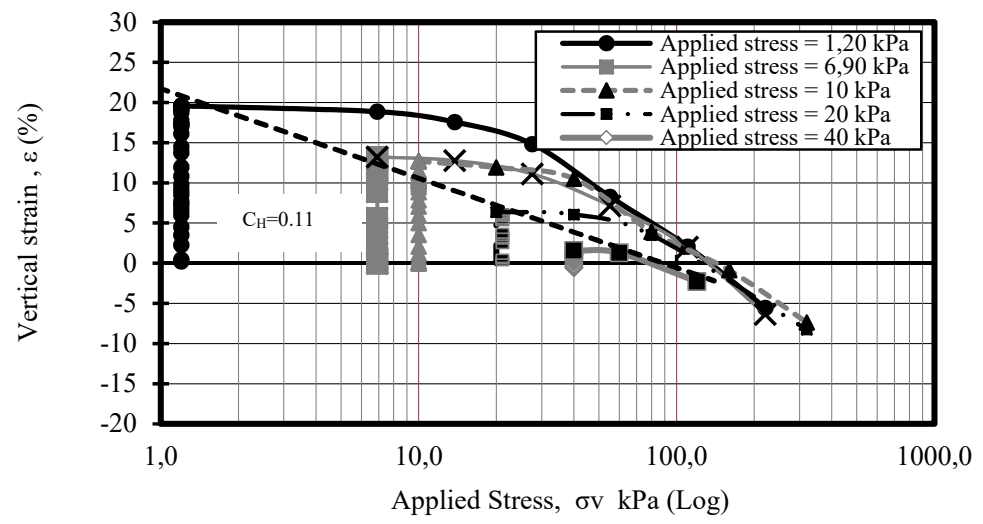

Fig. 3. The oedometer test results for different value of applied forces.

Table 3. Free field heave computation using equation (2)

\begin{tabular}{|l|l|l|l|l|l|l|l|}
\hline $\begin{array}{c}\text { Depth } \\
\text { to } \\
\text { bottom } \\
\text { of layer } \\
\text { (cm) }\end{array}$ & $\begin{array}{c}\text { Interv } \\
\text { al (cm) }\end{array}$ & $\begin{array}{c}\text { Overburde } \\
\mathbf{n} \text { stress } \\
\mathbf{( k P a )}\end{array}$ & $\begin{array}{c}\text { Water } \\
\text { content } \\
\text { changes }\end{array}$ & $\begin{array}{c}\mathbf{C}_{\boldsymbol{\varepsilon}, \mathbf{w}} \\
\mathbf{s l o p e}\end{array}$ & $\begin{array}{c}\text { Increment } \\
\text { al heave } \\
\mathbf{( c m )}\end{array}$ & $\begin{array}{c}\text { Cumulativ } \\
\text { e heave } \\
\mathbf{( c m )}\end{array}$ & $\begin{array}{c}\text { Cummulativ } \\
\text { e heave } \\
\text { from entire } \\
\text { depth of } \\
\text { wetting (cm) }\end{array}$ \\
\hline 0 & & & & & & & 15,79 \\
10 & 10 & 0,95 & 36.21 & 1,07 & 3,87 & 3,87 & 11,92 \\
20 & 10 & 2,84 & 36.21 & 0,90 & 3,27 & 7,13 & 8,65 \\
30 & 10 & 4,73 & 36.21 & 0,83 & 3,02 & 10,16 & 5,63 \\
40 & 10 & 6,63 & 36.21 & 0,79 & 2,87 & 13,03 & 2,76 \\
50 & 10 & 8,52 & 36.21 & 0,76 & 2,76 & 15,79 & 0,00 \\
\hline
\end{tabular}

Table 4. Free field heave computation using equation (3)

\begin{tabular}{|c|c|c|c|c|c|c|}
\hline $\begin{array}{c}\text { Depth to } \\
\text { bottom } \\
\text { of layer } \\
\text { (cm) }\end{array}$ & $\begin{array}{c}\text { Interval } \\
\text { (cm) }\end{array}$ & $\begin{array}{c}\text { Total } \\
\text { unit } \\
\text { weight } \\
\left(\mathbf{k N} / \mathbf{m}^{3}\right)\end{array}$ & $\begin{array}{c}\text { Overburde } \\
\text { n stress } \\
\text { (kPa) }\end{array}$ & $\begin{array}{c}\text { Incrementa } \\
\text { I heave } \\
\text { (cm) }\end{array}$ & $\begin{array}{c}\text { Cumulativ } \\
\text { e heave } \\
\text { (cm) }\end{array}$ & $\begin{array}{c}\text { Cumulative } \\
\text { heave from } \\
\text { entire depth } \\
\text { of wetting } \\
\text { (cm) }\end{array}$ \\
\hline 0 & & & & & & 7,68 \\
\hline 10 & 10 & 19,30 & 0,95 & 2,20 & 2,20 & 5,48 \\
\hline 20 & 10 & 19,30 & 2,84 & 1,67 & 3,86 & 3,81 \\
\hline 30 & 10 & 19,30 & 4,73 & 1,42 & 5,28 & 2,39 \\
\hline 40 & 10 & 19,30 & 6,63 & 1,26 & 6,54 & 1,14 \\
\hline 50 & 10 & 19,30 & 8,52 & 1,14 & 7,68 & 0,00 \\
\hline
\end{tabular}

\section{Comparisons of free field heave prediction}

Fig. 4 presents a comparison of the heave profile between the free field heave prediction by using Marr et al. method and Nelson et al. method, with a measured heave from heave testing in the laboratory. 


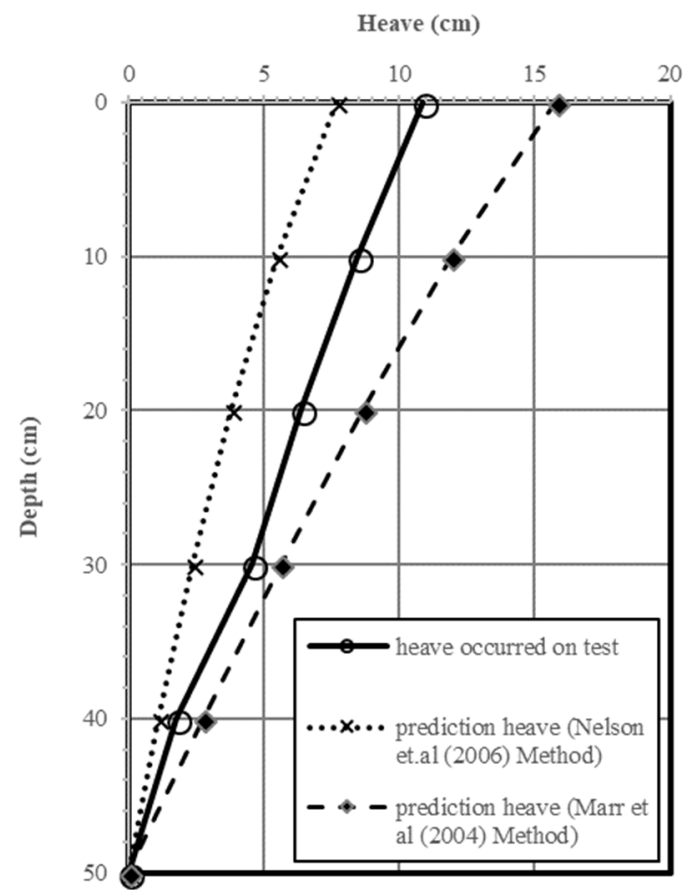

Fig. 4. The comparison of the heave profile throughout depth of soil between predicted and measurement.

The following observations are based on the comparison,

a. Both the Marr et al. method [3] and Nelson et al. method [14] provided predictions that lie below and above the heave measurements, respectively. These two prediction methods provided results that represent low and upper bound predictions of the true soil heave movement in the laboratory. However, the Nelson et al. prediction method was closer to the heave measurements. The difference between the Nelson et al. prediction and Marr et al. prediction with heave measurement was about $29,50 \%$ and $45,02 \%$, respectively. The high prediction by Marr et al. method can be attributed to the swell pressure parameter that was not taken into account in the heave prediction, only considering applied stress, strain, and water content changes.

b. The heave prediction result showed similar trends as those observed in the laboratory heave measurements.

c. Both prediction methods can be used to estimate heave since the initial soil condition (water content and dry density) and applied stress are the same condition between the sample used in the oedometer test and soil samples that compacted in the heave testing box.

The advantage of the Marr et al. predictions method is that the method can be made using only water content data, and the data resulted from a fairly routine geotechnical laboratory test which means that most geotechnical engineering laboratories are well equipped to set up and run the test. But, the test procedures take a long time (time-consuming) to set up and to run the shrink-swell test. Furthermore, the test procedure needs a lot of specimens that are identical and it is difficult to ascertain whether that specimens prepared are identical.

The $\mathrm{CH}$ parameter that was used in the Nelson et al. prediction method is more rigorous, and it is based on considerations of both applied stress and suction as well as water content. 
But both $\mathrm{CS}$ and $\mathrm{CV}$ tests are needed to determine the $\mathrm{CH}$ parameter, in routine geotechnical laboratory, only the CS test is conducted, hence only CS swelling pressure is measured. One of the proposed methods for determining $\mathrm{CH}$ parameters was the m method, as used in this study. The value of $\mathrm{m}$ falls below 2 [8]. In this study $\mathrm{m}$ value was 0.11 . The most frequent $\mathrm{m}$ values (mode) range from 0 to 0.4 if the value of $\mathrm{m}$ is varied outside of an appropriate range the predicted heave will be more sensitive to the amount of $\mathrm{m}$ [8]. Thus, the heave prediction using the Nelson et al. method is influenced by the quality of the oedometer test results, the accuracy in determining the $\mathrm{CV}$ swelling pressure and the $\mathrm{CH}$ parameter.

\section{Summary and conclusions}

This study presented not only heave prediction methods based on oedometer data but also the comparison between free field heave measurement with the heave prediction. The parameter that needs to predict the heave by using oedometer data has been determined. The limitation and the advantage of each prediction method was identified.

Based on the result obtained, the conclusions are as follows, the heave prediction result showed similar trends as those observed in the laboratory heave measurements, both the Marr et al. method and Nelson et al. method provided predictions that lie below and above the heave measurements, respectively. However, for the Ngawi expansive soil that was used in this study, the Nelson et al. prediction method was closer to the heave measurements. The difference between the Nelson et al. prediction and Marr et al. prediction with heave measurement in the laboratory was about $29,50 \%$ and $45,02 \%$, respectively.

Further studies need to be carried out to validate this heave measurement with other heave prediction methods.

This paper is part of a research sponsored by the Ministry of Research, Technology, and Higher Education in 2017-2018 under the National Strategic Research Grant number DIPA042.06.1401516/2018.

\section{References}

1 S. K. Vanapalli, L. Lu, A State-of-the Art Review of 1-D Heave Prediction Methods For Expansive Soils, International Journal of Geotechnical Engineering, vol. 6, pp. 15-41, (2012).

2 Y. Gao, D. Sun, Y. Wu, Volume Change Behaviour of Unsaturated Compacted Weakly Expansive soils, Bulletin of Engineering Geology and The Enviroment, pp. 1-12, (2017).

3 S. A. Marr, B. R. Gilbert, F. A. Rauch, A Practical Method For Predicting Expansive Soil Behavior, Geotechnical Engineering for Transportation Project, pp. 1144-1152, (2004).

4 H. H. Adem, S. K. Vanapalli, Heave Prediction in a Natural Unsaturated Expansive Soil Deposit Under a Light Loaded Structured, Geotechnical and Geological Engineering, vol. 34, pp. 1181-1192, (2016). 
5 W. K. Wray, B. M. El-Garhy, A. A. Youssef, Three-Dimensional Model for Moisture and Volume Changes Prediction in Expansive Soils, Journal of Geotechnical and Geoenviromental Engineering, vol. 131, pp. 311-324, (2005).

6 X. Zhang, J.-L. Briaud, Couple water content method for shrink and swell prediction, Transportation Research Board (TRB) Annual Meeting, Washington, (2006).

7 A. W. Dhowian, Field Performance of Expansive Shale Formation, JKAU: Engineering Science, vol. 2, pp. 165-182, (1990).

8 J. D. Nelson, K. C. Chao, D. D. Overton et E. J. Nelson, Foundation Engineering For Expansive Soil, New Jersey: John Wiley \& Son, (2015).

9 M. A. Al-shamrani, A. I. Al-Mhaidib, Swelling Behavior Under Oedometric and Triaxial Loading Condition, Advances in Unsaturated Geotechnics GeoDenver 2000, Denver, Colorado, (2000).

10 ASTM D4546, Standard Test Methods For One-Dimensional Swell or Settlement Potential of Cohesive Soils, West Conshohocken, PA: ASTM, (2003).

11 A. I. Al-Mhaidib, Swelling Behaviour of Expansive Shale From The Middle Region of Saudi Arabia, Geotechnical and Geological Engineering, vol. 16, pp. 291-307, (1999).

12 M. A. Al-Shamrani, A. W. Dhowian, Experimental Study of Lateral Restrain Effect on Potential Heave of Expansive Soils, Engineering Geology, pp. 63-81, (2003).

13 D. G. Fredlund, Prediction of Ground Movements in Swelling Clays, $31^{\text {st }}$ Annual Soil Mechanics and Foundation Engineering Conference, Minneapolis, (1983).

14 J. D. Nelson, D. D. Overton, K.-C. Chao, Evolution of Foundation Design for Expansive Soils, Geo-volution ASCE, pp. 62-75, (2006).

15 J. D. Nelson, D. K. Reichler, J. M. Cumbers, Parameter for Heave Prediction by Oedometer Test, Unsaturated Soil, vol. 147, pp. 951-961, (2006).

16 R. W. Thompson, H. A. Perko, W. D. Rethamel,Comparison of Constant Volume Swell Pressure and Oedometer Load-Back Pressure, Unsaturated Soil, pp. 1787-1998, (2006).

17 J. D. Nelson, K. C. Chao, Relationship Between Swelling Pressure Determined by Constant Volume and Consolidation-swell Oedometer Tests, Conference on unsaturated Soils, Sydney, (2014). 